\title{
The time of the Roma in times of crisis: Where has European neoliberal capitalism failed?
}

\author{
Spyros Themelis
}

University of East Anglia, UK

\begin{abstract}
This paper argues that the economic and financial crisis that has ensnared Europe from the late 2000s has been instrumental in reshaping employment and social relations in a detrimental way for the majority of the European people. It argues that the crisis has exacerbated the socio-economic position of most Roma people, immigrants as well as of other vulnerable groups. This development is approached here as an outcome of the widening structural inequalities that underpin the crisis within an increasingly neoliberalised Europe. Through recent policy developments and public discourses from a number of European countries I show how rising inequalities nurture racialised social tensions. My account draws on classic and contemporary theoretical propositions that have been propounded about the nature of capitalism, its contemporary re-articulation as well as its ramification for the future of Europe.
\end{abstract}

\section{Keywords}

Crisis, European Union, neoliberalism, Roma, scapegoating, working class

\section{Introduction}

This paper argues that during crises levels of hostility against the perceived 'other', that is to say immigrant workers, refugees, asylum seekers and so on, increase exponentially. My focus is on the largest minority in Europe, the Roma, who have been construed as the perennial 'other' in most European societies they live in. More recently, the Roma have been at the receiving end of acts of intolerance, scapegoating, racism and negative discrimination, ranging from physical abuse and harassment to racially motivated pogroms and expulsions from places they legally abide in and, invariably, have historical ties with. The Roma, more than any other 
minority group, are routinely demonised and have come to occupy the position of the 'convenient scapegoat' for European nation-states' inability to provide solutions to their economic and political woes, the growing socio-economic inequalities between the rich and the poor, the usurping of the national and global wealth by the few and, consequently, the emiseration of the many.

I explore some of the factors underlying these developments and analyse their implications in a dialectical manner, that is to say in a way that is concerned with the Roma relationally and not in isolation from their counterparts, that is the working people of Europe. The latter, the European workforce, has sustained a continuous attack in the last 30 years or so. For example, in the UK workers have incurred a sustained income compression and reduction in social welfare (OBR, in TUC, 2013). In Germany they have suffered a sustained income loss, along with a reduction in unemployment benefits, and pension rights (Lapavitsas et al., 2010), while in some countries of the periphery, such as Ireland, Greece, Spain and Portugal, workers have experienced sharp income drops, significant abolition of welfare protection and job lossesi. Almost without exception, workers in European countries have abolished employment rights, security of employment and have endured a concomitant deterioration in their working and living standards.

These circumstances have coincided with conditions of political apathy, social anomie and economic catastrophe, which are underpinned by ideological polarisation and confusion over working people's alliances, ties and solidarities. The leadership of the European Union and most of its member states have been integral in engineering the entrapment of the working people of Europe. The latter, are increasingly and perilously obfuscating the deteriorating working and living conditions they experience with the rise of an artificial threat, that of the Roma, specifically, as well as immigrant workers and any kind of 'others', more broadly. Thus, instead of channeling their anger at the emiseration and collective degradation of life and employment standards that has been affecting the vast majority of the European workforce, they adopt the media-fuelled propaganda and delve into a witch-hunt against the Roma, immigrants, Muslim people and anyone that occupies a marginal and often stigmatised role in their societies. 
The current crisis has given impulse to feelings of insecurity, marginalisation and victimisation among minority groups, such as the Roma, while, at the same time, it has led to the criminalisation and mounting hostility against them that takes the form of abuse and pogroms, racially-motivated attacks, expulsion and further stigmatisation. In this context, the virulence of the persecution of such groups in many European countries, such as France, Germany, Italy, the UK, Greece and elsewhere, are approached not only as outcomes of the current economic crisis, but also as a concerted effort to restore class power from above. That is to say, they are structural characteristics interwoven into the current stage of capitalism, namely neoliberal capitalism, as it is unfolding in the European landscape, rather than aberrations from 'normality'. They are the ugly, yet true face of Europe: a form of 'European Realism', that is to say a crude representation and encapsulation of the social relations in the richest economic area in the world.

My intention in this paper is to offer an appraisal of aspects of current neoliberal capitalism within Europe and demonstrate its role in nurturing racial tensions through the reshaping of the relations of production and the scapegoating of minority groups, such as the Roma. My account is informed by contemporary critiques of neoliberal capitalism (Harvey, 2005; Žižek, 2010) but also by classical critical theory, such as Horkheimer and Adorno's [1944] (1973) account about the rise of anti-Semitism in pre-Second World War Europe. The paper begins with the explication of some key tenets of the recent economic crisis as it is manifest in Europe. It then moves on to the presentation of some instantiations of the crisis in powerful European countries, such as France, the UK and Germany. The third part, draws lessons from the European history and the Holocaust in making the case for a departure from the socalled 'Roma problem' to focusing on the problematic system that gives rise to such artificial problems. Finally, in the conclusion I discuss some historical antecedents of the current crisis, the rearticulation of which could serve as an opportunity to move beyond dominant approaches that contribute to the plight of the Roma (and other minority groups) and could offer an exit from the current impasse of capitalism that is threatening the working people of Europe.

\section{Crisis in Europe and Europe in crisis}

The beginning of one of the most serious financial and economic crises in the history 
of capitalism is thought to be in 2006 in the USA, where house repossessions started spreading uncontrollably (Harvey, 2010). In September 2008 the investment bank Lehman Brothers went bust and the shockwaves spread rapidly across the globe. Since then, many pundits, experts and market specialists have vehemently argued that the crisis could have been aborted. A case in point is a report into the reasons that led to the financial crisis by the US government-appointed Financial Crisis Inquiry Commission (FCIC) (2011), which unequivocally concluded that the crisis was preventable. The report stated that its causes were, among other factors, extensive failures in financial regulation, remarkable breakdowns in corporate governance, ill-prepared policymakers with a lack of a 'full understanding of the financial system they oversaw' (2011, p. xxi) and, intriguingly, systemic lack and/or breach of accountability and the code of ethics at all levels. In other words, this was not an inescapable catastrophe but a calamity that involved governments, institutions and powerful financial, economic and political actors. Yet, this begs the question: if the crisis was preventable, why did it occur in the first place? Or, more importantly, given that precious little was done to prevent the crisis, could the latter have been welcomed by some (powerful) actors as an opportunity to radically reform the system or some aspects within it?

This requires a closer look at what 'crisis' really means within capitalism. Texts in political economic theory emphasise the nature of the capitalist system of production and its insatiable demand for new markets (McLaren and Farahmandpour, 2005; Harman, 2009). More than that, they demonstrate how crises are inbuilt in the capitalist mode of production and, in effect, a sine qua non of its continuous quest for quantitative development (Luxemburg, (1971)[1899/1908] ; Kautsky, 1982). Marx's (1990)[1867]; (1967)[1894] original analysis explicated the way in which capital operates and highlighted the inherent conflict between labour and capital. According to his thesis (Marx, (1967)[1894]) on the tendency of the rate of profit to decline, when this happens, as is the case with the current global recession, various factors can be activated in order to ameliorate the consequences. In other words, capitalism has the ability and flexibility to activate some mechanisms or counteracting factors that can mitigate this tendency described above and enable the system to return the system into profitability. One of these mechanisms is the reduction of wages and labour cost compression, which can be accompanied by similar mechanisms, such 
as the creation and preservation of a surplus population (see high unemployment) and the increase in the exploitation of labour.

This points to the fostering of the conditions for the exploitation of the workforce, the deterioration of their employment conditions, the increase in unemployment, the usurping of their protection and employment rights, including pension rights, welfare protection, education, health and other services that were put in place after the WWII in order to secure capitalism's longevity. It is suggested that what the European working class is experiencing in this conjuncture is an onslaught that points to the second option that capitalism has available as a means of exiting the crisis. In other words, capitalism targets the working class in an attempt to reverse the falling rate of profit on a global scale, which is what led to the economic crisis in the first place.

In order to shed light on these developments, I discuss how the crisis has been profoundly transforming the world of employment and social relations. As growth diminishes (or stays at very low levels) jobs are getting lost by the day. At the same time, the occupational structure is being reshaped while the labour market is also undergoing radical changes. Some argue that a yet more flexible economy is in the making while others talk about the further casualisation of employment, a serious loss in workers' rights and the worsening of working conditions (Callinicos, 2010). Although the precise impact of these developments on the European Roma is less well known, the ramifications for groups with similar characteristics, that is to say with low socio-economic background are discernible. For example, the economic crisis has led to high unemployment, which has become one of the most pressing issues in Europe. Characteristically, in late 2010 and early 2011, 15 out the 27 European Union countries had unemployment rates of over $8 \%$ while 10 countries saw unemployment rising beyond 11\% (Eurostat, 2011). In late 2013, unemployment in the Eurozone area was $12.2 \%$, while five of its member-states (namely, Portugal, Cyprus, Croatia, Spain and Greece) had higher unemployment than 15\% (Eurostat, 2013). In other words, unemployment has become the matrix of socio-economic failure for many European countries while the labour market has become the field par excellence of the denial of the right to employment and concomitant exclusion of a sizable part of European citizenry from key institutions as well as social, economic and civic activities. 
Among other things, unemployment is associated with lower levels of physical and mental health (Jin et al, 1995). In addition, unemployment and economic insecurity play a significant role in the reshaping of social relations. A recent study by the Europe Commission against Racism and Intolerance (ECRI, 2010) pointed out that racism has soared during the current economic crisis and immigrants, foreigners and other marginalised groups, such as the Roma, are increasingly identified as the victims of intolerance, negative discrimination and racism. In addition, as far as the Roma are concerned, they have been associated with sustained acts of discrimination both at an institutional as well at a personal level (OSCE, 2008). The history and intensity of the hostility and marginalisation of the Roma has been extensively discussed elsewhere (Liégeois, 2007; Revenga et al., 2002). While it manifestly predates the current financial and economic crisis, it has been accentuated by it and has taken new dimensions. Here, I focus on the hostility against the Roma in Europe that coincided with the crisis.

\section{The time of the Roma in times of crisis}

While some Roma groups lead a nomadic or semi-nomadic lifestyle, this is mainly pursued within a single country of residence. In any case, the majority of Roma people lead sedentary lifestyles (Liégeois, 1994). The European Roma are historically rooted in most countries in which they currently live. In other words, the historical embeddedness of the European Roma cannot be disputed more than for any other European group (Themelis, 2008). This feature makes them 'a true European minority' (Council of Europe, 1993). Nevertheless, the European Roma are in many contexts perceived as transient, foreign, or even 'alien' groups (Bhopal and Myers, 2008).

In the recent years rising hostility has been evidenced against many European Roma groups and, especially after 2008, their living and working conditions have dramatically deteriorated. I start by exemplifying the link between the economic crisis and the worsening of the treatment of Roma groups by focusing on France, a country that had been wrestling with social unrest and rising dissent by its disaffected urban and suburban population since the new millennium. I then present some other examples of anti-Roma (and anti-immigrant) hostility in other European countries, in 
order to explain the relationship between the reshaping of neoliberal capitalism and enmity against the 'other'. In October 2005, the forgotten youth of Paris, that is unemployed teenagers 'from destitute suburban housing projects' (Sahlins, 2006), took to the streets after the electrocution of two French youths of Malian and Tunisian descent, who were trying to flee the police. The protests soon spread to more than 274 towns within the city of Paris and beyond. As a result, several schools and other public buildings, and approximately 10,000 cars incinerated in three weeks of civil unrest. In March 2009, Muslim youth clashed anew with the police, while tensions and uprisings in the French capital seemed to be interwoven in its contemporary social fabric. At the same time, the far-right, represented politically by the Front National, was raising its political influence among the disaffected urban working class and all those discontent with and affected by the rising unemployment and inequalities in the French society and the declining living standards.

To all these acute social problems the French government responded with disproportionate force against the Roma (and immigrants), a set of acts with high symbolic significance. To be precise, the expulsion of approximately 700 Roma people with Romanian and Bulgarian background from various sites in France in August 2010 was shocking, though not without precedent. In July of the same year, the French national assembly passed a law that banned the Islamic face covering. In the 'face of it', this is about women's emancipation and, in effect, about 'égalité', one of the cornerstones of the French Republic. However, something else was at play here. As Scott (2010) put it, this was 'part of a campaign to purify and protect national identity, purging so-called foreign elements - although many of these "foreigners" are actually French citizens - from membership in the nation'. It is part of an inimical bid by the then French president Nicolas Sarkozy and his government 'to capture the anti-immigrant, anti-Muslim [and anti-Roma] animus that has brought electoral gains to the rightwing National Front party and to disarm the Socialist opposition, which has so far offered little resistance to the xenophobic campaign' (Scott, 2010). Lest there are any doubts about the determination of the French government of the time to make political capital from the situation, it chose that moment to announce another two policies directed against the Roma and immigrants, namely 'the criminalisation of entire families rather than just individuals and the stripping of citizenship from immigrants with criminal convictions' (Brooks, 
2010). The dynamism of the French government has been described as 'a chilling moment in French history, a cynical mobilisation of racist feeling that risks unleashing an even worse atmosphere of pogrom and violence against minorities, immigrants and all black people' (Kimber, 2010).

But what was the ulterior meaning of the Sarkozy government's actions against the Roma and immigrants? How can we understand and explain the attack on groups who occupy a marginal position in the labour market and pose no threat to the French state and the rest of the workforce? Understanding France, means understanding contemporary Europe. The French government aimed to show that it can be taken seriously by its European counterparts and its domestic electorate. The point it was trying to make was that France is a masterful state who is willing and able to exercise its force, no matter how brute and disproportionate, when it deems appropriate. The deportation of a few hundreds of Roma people did not resolve the social, economic or other problems facing France. Sending back to Romania and Bulgaria children, who comprised a big proportion of the Roma people under attack, has to be seen as a symbolic act by the French government to show its resoluteness to exercise control in its own territory, that it can put its house in order. But who is the French government trying to persuade of its ability to bring 'order'? What is at stake here? The French government's intention was to create a scapegoat, that is to say 'an easy target for politicians seeking to distract attention from problems at home by playing on fears over security' (Hollinger and Bryant, 2010). In addition, there was something bigger at stake here. Despite the fact that the prime audience of the French government was the domestic electorate, some lessons for the rest of Europe can be extrapolated. France plays a leading role in Europe and, together with Germany, they are at the helm of the Eurozone economy. The impact of domestic actions in either of these countries extends far beyond their borders as the two countries have the ability to influence the policies of their counterparts within the Eurozone and European Union more broadly.

Incidentally, similarly tough measures against the Roma were announced at the same time in Germany, though the latter initially publicly distanced itself from the French approach. Specifically, in the summer of 2010 Germany forcefully repatriated to Kosovo approximately 12,000 Roma, Ashkali and Egyptians. This massive act of 
repatriation was undertaken without due consideration of the wellbeing of deportees and the most vulnerable among them, the children. According to a report by UNICEF (2010, p. 7) serious concerns were raised about 'the return of individuals without a secure residence status to Kosovo', as well as about the fact that 'the best interests of these children have not so far been considered a priority, despite the fact that over half of these individuals with Roma background are children and almost two-thirds of them were born and have grown up in Germany'. For the German government it was more important to flex its muscle by yielding incommensurate force to eliminate an artificial problem, rather than use its sizable economic and political power to resolve it. Taking into account the conditions that awaited those forcefully repatriated, there is little doubt over Germany's real motives:

'Three out of four returned children no longer attend school in Kosovo. A considerable number do not possess a birth certificate and are therefore unable to exercise their right to educational, medical or welfare services. Severe trauma and chronic illness among many of the adults in these families, whether in Germany or Kosovo, mean that too many children are obliged to take on too much responsibility too early in life (UNICEF, 2010, p. 8).

The aggressive approach of both the French and German governments, were swiftly emulated by the UK, who prepared legislation, also in the summer of 2010 , allowing its authorities to evict Roma and Traveller families from campsites they abide in. This follows forced evictions, such as of residents in the Dale Fare, a Traveller camp site in Essex, South East England. The local council, namely Basildon, decided to devote close to a third of its annual budget, that is $£ 8$ millionii (BBC, 2012), in order to evict 86 Traveller families in what was coined as the 'battle of Basildon' (Barkham, 2011). Thus, the shift to the terrain of legitimate 'Romanophobia' and state-subsidised antiGypsyism was successfully marked and would soon become the new 'realpolitik' within the UK. David Cameron, the British Prime Minister, signaled this turn through a carefully-crafted speech he delivered to a German audience in February 2011:

'We must build stronger societies and stronger identities at home. Frankly, we need a lot less of the passive tolerance of recent years and a much more active, muscular liberalism. A passively tolerant society says to its citizens, as long as you obey the law we will just leave you alone. It stands neutral between different values. But I 
believe a genuinely liberal country does much more; it believes in certain values and actively promotes them. Freedom of speech, freedom of worship, democracy, the rule of law, equal rights regardless of race, sex or sexuality. It says to its citizens, this is what defines us as a society: to belong here is to believe in these things'.

Cameron chose strategically this occasion to proclaim the death of multiculturalism and the need to unite around the values of an ill-defined 'muscular liberalism'. Not only did he seek to express his alignment with Germany on issues of immigration, border control and the growing intolerance in both countries against Muslims, immigrants and the Roma, he also intended to make political gains against the growing influence of the far-rightiii. The quest for 'stronger societies' that Cameron advocates in his speech is to be based on the creation of 'stronger identities at home'. And a predicament in fostering such identities is 'passive tolerance'. In terms of applied public policy, this can be understood as follows: tolerating the existence of some Roma families who live in the Dale Farm is part of a passe, wrong kind of liberalism. Juxtapose this to the right kind, that is 'muscular liberalism' that Cameron heralded, which is underpinned by the active promotion of 'certain values', such as 'freedom of speech, freedom of worship, democracy, the rule of law, equal rights regardless of race, sex or sexuality'. However, the people who were targeted by the UK's 'muscular policies', such as the evicted residents of the Dale Farm, are not against the values Cameron highlighted in his speech. For it is an insular and duplicitous form of liberalism and multiculturalism that Cameron purports. On one hand, it respects diversity, but on the other it seeks to dismantle it by creating a stronger sense of 'us' and 'them'. By telling a German audience 'to belong here is to believe in these things', Cameron is alluding to a purified, dominant and powerful group within Europe that has the right to be protected by any perceived threats. In doing so, he was pledging allegiance to the most powerful European leader, Angela Merkel, who was keen to recruit allies in suppressing any group(s) who dared threat this newly-formed liberalism, no matter how vaguely the latter was defined. This type of liberalism, I argue, is European neoliberalism in disguise, that is the new form of organisation that is emerging from the ashes of financial and economic meltdown. Its main difference from its predecessor is that while it upholds allegiance to the basic human rights, the rule of law and democracy, it concurrently seeks to 
compartmentalise dismantle and eventually dismantle them.

Consonant with this type of European neoliberalism is the principle underpinning the state-led expulsions of the Roma in France, Germany and the UK and other countries. In this way a unifying form of discrimination is created by powerful European states with the pretext of acting to protect human and other rights for the majority of their citizens. Invoking liberal values has been proven to be a sine qua non of political rhetoric as the European citizenry is sensitised to 'unreconstructed', ugly racism of, say the 1950s. The latter, would take the form of 'no Irish, no Roma' signs outside pubs, harassment, and verbal or physical abuse, but would now seem as an anathema to the liberal consensus. Nevertheless, the tensions this liberal pact masks are not to be underestimated. As Žižek (2010) points out:

'Progressive liberals are, of course, horrified by such populist racism. However, a closer look reveals how their multicultural tolerance and respect of differences share with those who oppose immigration the need to keep others at a proper distance. "The others are OK, I respect them," the liberals say, "but they must not intrude too much on my own space. The moment they do, they harass me."

The examples offered above are only a few selected ones in terms of economically advanced European countries that waged an overt attack against the perceived 'others', such as the Roma. Sadly, they are not the only ones. In 2008, Italy shocked Europe with its adoption of a fingerprinting scheme for all Roma people living within its borders. Although the policy was initially condemned by the European Parliament, it was eventually approved by the European Commission (OSCE, 2008). Similarly, Denmark contravened EU legislation in order to deport what it described as the 'criminal Roma'. In the Czech Republic, entire communities have been harassed by far-right organisations under the nose of the local authorities. In Greece, 'a series of (quasi-) judicial decisions regarding some aspects of [...] discrimination, namely racist police violence, inadequate housing and evictions and exclusion from or segregation in education have been ignored by Greek authorities' (Dimitras, 2010), while similar accounts can also be drawn from other European countries.

The governments of European states, and especially some powerful ones among them, such as France, Germany and the UK, share some crucial characteristics. First, the force they use against some of the most marginalised groups in their 
societies is disproportionate to the threat posed by the latter. In fact, this force only serves to reassert the powerlessness of the targeted groups. At the same time, though, it serves as a reminder of the real interests of the state, reaffirmed as they are in times of crisis. Hence, instead of protecting the most vulnerable the state becomes a force field that internalises class relations (Harvey, 2005, p. 11), in that it exerts its power, real and symbolic, to deny subordinated groups the right to adobe, employment, health, education and so on. The message of this type of acts of stateviolence is simple: in dire economic conditions the state is poised to protect its 'true' citizens from 'episodic intruders', such as immigrants, and unwanted others, such as the Roma. Secondly, these selfsame nation-states do nothing to deal with the problems endemic in their countries, such as unacceptably high unemployment, spiraling social inequalities, unprecedented poverty rise, continuously suppressed wages and so on. By contrast, they create new target groups and choose to recycle their stigmatising practices against existing ones, in order to obfuscate the real issues threatening their societies. That is, they mask the shifting of class power from the poor to the rich and the further worsening of the position of the working class, who is divided between 'native' and 'alien' workforce and, thusly, occluded from taking meaningful action against those truly responsible for its sinking, namely those who exploit it.

\section{Crisis opportunism and the specter of the Holocaust}

In recent years, immigration in Europe as well as dealing with the 'other' has become one of the most fervently debated topics. It would not be an exaggeration to claim that, in some countries at least, these issues have triggered a 'moral panic' (Cohen, 1972). Although the positive benefits from immigration for the host country have been lucidly documented (Facchini and Mayda, 2008), many European countries, such France and Germany, have been undeterred from excluding immigrants, documented and undocumented alike, from receiving welfare benefits (Escandell and Ceobanu, 2009). In a similar fashion, other countries, such as Spain, Italy and the UK, have reformed their entry and citizenship criteria in order to impose limits on immigration. In the logic of those who designed them, these policies are justified by the new reality the financial and economic crisis has brought about. This has blithely led to the mainstreaming of a 'blame-the-foreigners' approach, which, purportedly, protects the native workforce from labour market rigidities. That is to say, when the 
pie is shrinking, having fewer members sharing it, can act as a 'relieving valve'. Against this systemic view, I argue that this line of reasoning is nothing but a smokescreen for a concerted effort on behalf of the ruling class to renew the rules of submission of labour into capital. Thusly, the resultant division of the workforce, and society at large, into 'us' and 'them', ruptures existing solidarities and aborts the possibility of establishing new ones. As such it has to be viewed as an orchestrated attack against the unity of the labour force and a lever against the formation of potential class alliances. This is facilitated, mediated and materialised through apposite ideological propositions, such as the one that views economic crises as opportunities.

This 'crisis opportunism' and the reasoning behind it has been underpinning and permeating the financial and economic crisis that started in 2008 and has now ensnared Europe. According to it, a crisis is welcomed as a way of breaking away with the old state of affairs, which includes any 'social contracts' governments had forged to protect the democratic, welfare, civil, labour and other rights of their citizens. Hence, crises are not invidious, so long as they can be exploited as a means of promoting the dicta of the new phase of neoliberal capitalism. This attitude to crises has been repeatedly ( $p$ )raised in mainstream media and was most lucidly exemplified by Rahm Emanuel, Barack Obama's chief-of-staff (in Blinder, 2009) 'You don't ever want a serious crisis to go to waste; it's an opportunity to do important things that you would otherwise avoid'. To be precise, it was in the early-1990s that the global elite formulated a vision for a new world order where crises could enable governments to cut back social, economic and political gains that have been achieved in the first four decades after the Second World War. John Williamson (1994), the man who was instrumental in the conference that gave birth to the socalled 'Washington Consensus'iv, emphatically exclaimed: "the worst of times give rise to the best opportunities for those who understand the need for fundamental economic reform". This is not only the moment when crisis-opportunism was born, but, crucially, when it was given an ideological justification for much of the state restructuring and policy impetus that would follow. This approach exemplifies the 'new spirit of capitalism' (Boltanski and Chiapello, 2005) that has triumphantly reasserted itself after the end of the Cold War, the termination of which has found capitalism bouncing back as the only system of socio-economic and political organisation. In such as context, capitalism has found fertile conditions to be further 
entrenched as a totalising system that it is, but also to assert itself as a monopoly system. That is to say, as a system that is no longer interested in respecting and sustaining traditional entities, such as the nation-state, neither institutions and arrangements that have been fundamental in the post-war period in a majority of European countries, such as the welfare state.

While crises are inherent features of capitalist development, as argued above, the exploitation and even manufacturing of crises on a grand scale, such as the one that threatens to dismantle the Eurozone and especially the periphery of the European Union, are characteristic of the current and most virulent stage of capitalism yet, namely neoliberal capitalism. In this vein, we should not be taken aback by the inability of European governments to safeguard the return to social stability, economic growth and political credibility even of the quasi-democratic political system European citizens used to enjoy until recently. Instead we ought to identify, explicate and openly discuss the origins of the current crisis in order to expose it for what it is: a welcomed opportunity for the ruling class to reorganise production and employment against the interests of the working people of Europe.

In this light, the resurgence in the marginalisation and stigmatisation of Roma and other minority groups within Europe has to be approached as an outcome of the reorganisation of labour and restructuring of class relations. According to one of the richest people in the world, Warren Buffet 'there's been class warfare going on for the last 20 years, and my class has won' (Buffett, 2011, in Sargent). This win of capital against labour is the product of the restoration of class power that neoliberal capitalism has ushered in (Harvey, 2005). This entails the suppression of wages, the enhancement of flexibility in the workplace, the deterioration of working conditions, the intensification of precarious employment, in a nutshell the 'dismantling of the world of work' (Boltanski and Chiapello, 2005). The workers then, instead of mobilising to protect their rights in unison with the other oppressed segments of the workforce, are split between 'native' and 'foreigner' labourers, 'us' and 'them', and are fighting against a set of 'ghost enemy', such as the Roma, immigrants and any other groups conveniently constructed as the 'other'. That is to say, instead of combating structural injustices that lie at the core of the capitalist system of production, the labourforce is invited to compartmentalise these issues by ethnicising them. In this way, systemic failures of the capitalist production are masked under the rubric of 
'ethnic differences', lack of inclusion of specific groups, incompatibility of lifestyles between 'us' and 'them' and so on.

However, this is not a new situation. It is by now a familiar tactic employed by the ruling class to tear asunder the working class in pursuit of its own interests. A case in point is the fascist National Socialist party before the Second World War, which invented an enemy, namely the Jews, but also homosexual people, the Roma, communists and other groups, in order to divide the working class and justify the atrocities that would follow. In a similar fashion, nowadays, the Roma principally but also other minority groups, are being used as the enemy of the increasingly repressive and non-democratic European order in order to obfuscate the organised onslaught on the working class. This strategy turns the latter, namely the working class, against itself thusly further diminishing their chances of acting as a social class in-itself (Marx, (1955)[1847]) and disabling it from partaking in the reconstitution of class boundaries as well as the restoration of class power. The latter, the rebalancing of class power, is left entirely to the capitalist class, who act under the auspices of the state, which, in this instance is acting as the as an instrument for the restoration of class power from above, as an 'executive committee of the bourgeoisie' (Marx and Engels, (1977)[1848]). More specifically, the European nation-states have become void of any democratic, political, moral and axiological legitimacy and they are increasingly being transformed into arenas where local, that is national elites, compete for domination and access into the international markets and the global arena of capital. The unsuccessful life and slow death of the (people of the) Eurozone is nothing but an exemplification of this very war waged by the European ruling class in their fight for a bigger share in the global market. This route requires the subordination of the working class and is not travelled for the first time. As I argued in the previous sections, the selective scapegoating of immigrants and other minority groups has been consequential in shaping public attitudes, especially in times of crisis such as the current ones. While minority groups, such as the Roma, are more often blamed rather than recognised for their multiple contributions to the societies where they live in, since the beginning of the financial and economic crisis they have also taken the role of the collective scapegoat, the 'convenient enemy' (Fekete, 2009). This practice is deeply destabilising and socially divisive, as it places segments of the population against each other. Yet, this is not an entirely new 
phenomenon. The history of scapegoating and racism in Europe goes as far back as the establishment of the European nation-states and most recently played out in the tragic built up to the Second World War. Horkheimer and Adorno's [1944] (1973) lucid analysis serves as a powerful reminder of the creation of scapegoats in order to manipulate the mass of the working people and disguise the organised barbarism committed by the Nazis. According to this account, the targeting of the Jewsv was nothing but an act of concealment by the Nazi leadership of the National Socialist party of their intentions to dominate the working class:

'The Jews are today the group which, in practice and in theory, draws to itself the destructive urge which the wrong social order spontaneously produces. They are branded as absolute evil by absolute evil. [...] Now that power is no longer needed for economic reasons, the Jews are designated as its absolute object, existing merely for the exercise of power' [1944] (1973, p. 137).

The demonisation of the Jews, that is to say turning Jewish people into objects of evil by the Nazi apparatus, was not justified by the objective position in the relation to the means of production Jewish people occupied at that time nor by the power and influence they exercised in economic, political and social terms. Rather, it was orchestrated by the Nazis who aimed to hide from the German people the appropriation of goods and property the Nazis themselves confiscated from the Jews. The construction of the Jews as the 'evil within the German society', enabled the Nazi leadership to create a collective scapegoat, while the ultimate target was the German workers themselves: 'The workers who are the real target, are understandably not told as much to their faces. [...] In the image of the Jew which the racial nationalists hold up before the world they express their own essence. Their craving is for exclusive ownership, appropriation, unlimited power, and at any price.' [1944] (1973, p. 137).

The construction of the Jews as the negative principle, the 'absolute evil', was an effective way of transposing to the latter the characteristics of the former, that is of the Nazi leadership. For the Nazi pursuit for complete control and domination encompassed all domains of life: ideological, psychological, economic, social, 
political, spiritual and so on. The Nazis were in quest of an expedient way of rationalising and legitimising the extensive inequalities nested in the German society of the time. Instead then of distributing the wealth accumulated by the confiscation of Jewish property and assets, the Nazis manufactured the 'convenient enemy', the Jews. Thusly, they could conceal the rampant inequalities emanating from the sphere of production, and the reproduction of the conditions of total subordination of the working class. The latter, that is to say the working class, had two options: either to join the Nazis in venting their anger at the convenient enemy and assist them in their eventual obliteration, or stay impartial and allow the Nazis to complete their deadly job.

\section{Conclusion}

Although no organised crime of the scale and nature of the Nazi atrocities has since taken place in Europe, there are numerous other examples of ideologically-motivated conflict or even war used in order to divide the working people of Europe. These wars are invariably underpinned by a process of scapegoating and persecution of a relatively powerless and marginal minority, such as ethnic minorities in former Yugoslavia. Scapegoating and the construction of collective enemies is a practice that seems to reemerge ever stronger during times of economic recession and labour market restructuring. In the early 2000s in the UK, for example, this practice has found application in the demonisation of asylum seekers and refugees and their representation as 'bogus, as illegal immigrants and economic migrants scrounging at capital's gate and threatening capital's culture' (Fekete, 2001). This ideological postulation, which is invariably accompanied by analogous media frenzy, is appropriated by policy makers in order to legitimise the exclusion of these groups from the sharing of public resources and the distraction of the general public from the increasing inequality in the sharing of resources, the redistribution from the poor to the rich that has been occurring in the last 30 years or so. A big part of those targeted at that time were Eastern European Roma, who were used once gain as the convenient enemy to justify new anti-immigration policies.

More than a decade later and the deepening of the economic and financial crisis has exacerbated the socio-economic position of most European Roma, immigrants and 
other vulnerable groups. As such, this development has to be approached as an outcome of the widening of structural inequalities that have been accompanying the crisis within the increasingly neoliberalised Euroscape. In this conjuncture, most politicians in Europe 'would rather not examine the cause of the economic crisis roiling the continent-many were complicit in dismantling the checks and balances that eventually led to the current recession- "criminal gypsies" come in very handy.' (Hallinan, 2010). However, the recent history of Europe should serve as a reminder. As Bauman argued in his seminal 'Modernity and the Holocaust' (1989), lack of democracy was a problem for the Holocaust. European states, instead of sliding further down this anti-democratic and xenophobic road that burst asunder Europe in the 1940s, should remind themselves that 'what happened to the Jews has been instrumentalized and transformed into an ideology of legitimation for the present system.' (Postone, 1980, p. 98). The European Roma, while they are similarly used to instrumentalise and ideologically legitimise the structural violence and unfairness of the current system, they should not be left to have the fate of the Jews in the Holocaust. Perhaps more than than ever the ongoing socio-economic, democratic, and political crisis within Europe might unite the working people of Europe to defend all segments of society against the neoliberal assault and turn the crisis of the system into an opportunity for the people.

Acknowledgement: An early version of this paper formed part of the keynote presentation at the seminar 'Experiencing, Confronting and Analyzing Marginality:

Theoretical Advancements and Methodological Challenges', hosted by the National Institute of Minority Issues, Cluj Napoca, Romania, 2-3 September 2010. I would like to thank the organisers of that seminar as well as all the participants for their instructive comments. The usual disclaimer applies.

\section{References}

Balch, A. (2010) Managing labour migration in Europe: ideas knowledge and policy change,http://www.nytimes.com/2009/09/06/business/economy/06view.html?_r=0 Working Paper 184, CCIS, Center for Comparative Immigration Studies, San Diego University California. Available online:

http://ccis.ucsd.edu/wp-content/uploads/2010/02/WP184.pdf Barkham, (2011) 'Dale Farm Travellers eviction: the battle of Basildon', The Guardian, 25/03/11. Available online:

http://www.theguardian.com/society/2011/mar/25/dale-farm-travellers-evictionbasildon 
Bauman, Z. (1989) Modernity and the Holocaust. Cambridge: Cambridge: Polity Press.

Blinder, A.S. (2009) 'The Wait for Financial Reform'. The New York Times, 05/09/09. Available online: (last accessed: 25 November 2013).

BBC, (2012) Dale Farm travellers: Council eviction bill tops $£ 4.8 \mathrm{~m}$. Available online: http://www.bbc.co.uk/news/uk-england-essex-16866828 (accessed 13 December 2013).

Bhopal, K. and Myers, M. (2008) Insiders, Outsiders and Others: Gypsies and Identity. Hertfordshire: University of Hertfordshire Press.

Boltanski, L., and Chiapello, E. (2005) The New Spirit of Capitalism. London: Verso. Brooks, E. (2010) 'Stop this state persecution of Roma', The Guardian, 18/08/10. Available online:

http://www.guardian.co.uk/commentisfree/libertycentral/2010/aug/18/persecutionroma-must-stop

Callinicos, A. (2010) Bonfire of Illusions: The Twin Crises of the Liberal World. Cambridge: Polity Press.

Cameron, D. (2011) PM's speech at Munich Security Conference. Available online:

http://www.number10.gov.uk/news/speeches-and-transcripts/2011/02/pms-speechat-munich-security-conference-60293

Castels, S. and Miller, M.J. (2009) The Age of Migration: International Population Movements in the Modern World, Basingstoke: Palgrave MacMillan

Cohen, S. (1972) Folk Devils and Moral Panics. McGibbon and Kee Ltd.

Council of Europe (1993) Recommendation 1203 on Gypsies in Europe.

Parliamentary Assembly, Council of Europe

Dimitras, P. (2010) 'Greece's Non-Implementation of International (Quasi-)Judicial Decisions on Roma Issues'

Escandell and Ceobanu (2009) Anti-immigrant Sentiment and Welfare State Regimes in Europe, Working Paper 178, The Center for Comparative Immigration Studies

University of California, San Diego.

Europe Commission against Racism and Intolerance (ECRI) (2010) Annual Report on ECRI's Activities: covering the period from 1 January to 31 December 2010.

Available online:

http://www.coe.int///dghl/monitoring/ecri/activities/Annual_Reports/Annual\%20report 
\%202011.pdf

Eurostat (2013) Unemployment rates, seasonally adjusted, October 2013. Available online:

http://epp.eurostat.ec.europa.eu/statistics_explained/index.php?title=File:Unemploym ent_rates,_seasonally_adjusted,_October_2013.png\&filetimestamp $=2013112908590$ 3

Eurostar (2012) 'At risk of poverty or social exclusion in the EU27'. Available online:

http://europa.eu/rapid/press-release_STAT-13-28_en.htm

Eurostat (2011) 'Unemployment statistics'. Available online:

http://epp.eurostat.ec.europa.eu/statistics_explained/index.php/Unemployment_statis tics

Facchini, G., and Mayda, A.M. (2008) 'From individual attitudes towards migrants to migration policy outcomes: Theory and evidence', Economic Policy 56: 651-713.

Fekete, L. (2009) A Suitable Enemy: Racism, migration and Islamophobia in Europe. London: Pluto Press.

Fekete, L. (2001) 'The emergence of xeno-racism'. Institute of Race Relations. Available online: http://www.irr.org.uk/2001/september/ak000001.html

Financial Crisis Inquiry Commission (FCIC) (2011) 'The Financial Crisis Inquiry Report; Final Report of the National Commission on the Causes of the Financial and Economic Crisis in the United States. Washington: U.S. Government Printing Office. Available online:

http://www.gpo.gov/fdsys/pkg/GPO-FCIC/pdf/GPO-FCIC.pdf

Hallinan, C. (2010) The Roma: Europe's Favorite Scapegoat. The Epoch Times.

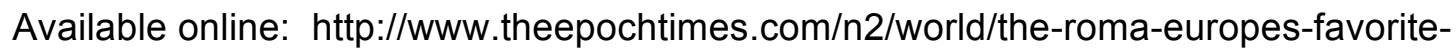
scapegoat-41787.html

Harman, C. (2009) Zombie Capitalism: Global Crisis and the Relevance of Marx.

London: Bookmarks Publications.

Harvey, D. (2005) A Brief History of Neoliberalism. New York: Oxford University Press.

Harvey, D. (2010) The Enigma of Capital and the Crises of Capitalism. London:

Profile Books Ltd.

Hollinger, P. and Bryant, C. (2010) 'Expelled Roma vow to return to France', Financial Times. Available online: http://www.ft.com/cms/s/0/7e7b81a8-ac8a-11df- 
8582-00144feabdc0.html\#axzz1QyckeUyR

Horkheimer and Adorno [1944] (1973) Dialectic of Enlightenment. London: Allen Lane.

Kautsky, K. The Class Struggle (CC) (1892) Translated by William E Bohn, Charles H Kerr, Chicago, 1910.

Kimber, C. (2010) 'Stop the persecution of Roma people, stop deportations from France', Socialist Worker. Available online:

http://www.socialistworker.co.uk/art.php?id=22200

Lapavitsas. C., Kaltenbrunner, N., Lambrinidis, G., Lindo, D., Meadway, J., Michell, J., Painceira, J.P., Pires, E., Powell, J., Stenfors, A. , Teles, N. 2010. The Eurozone between Austerity and Default, Research on Money and Finance, Occasional Report

Liégeois, J-P. (2007) Roma in Europe. Strasbourg: Council of Europe.

Liégeois, J.P. (1994) Roma, Gypsies, Travellers, Strasbourg: France.

Luxemburg, R. (1899/1908) [1971] Social Reform or Revolution, in Howard, D. (1971) (ed.) Selected Political Writings of Rosa Luxemburg. New York: Monthly Review Press.

Marx, K. (1990)[1867]. Capital, Volume I. London: Penguin Books.

Marx, K. (1967)[1894] Capital, Volume 3. New York: International Publishers.

Marx, K. (1955)[1847] The Poverty of Philosophy. Progress Publishers.

Marx, K. and Engels, F. [1848] (1977) Manifesto of the Communist Party, in Karl Marx and Frederick Engels, Selected Works. London: Lawrence \& Wishart.

McLaren, P. and Farahmandpour, R. (2005) "Marx after Post-Marxism: Reclaiming Critical Pedagogy for the Left," in P. McLaren (ed.), Red Seminars: Radical

Excursions into Educational Theory, Cultural Politics, and Pedagogy. Cresskill, NJ: Hampton Press Inc.

Office for Budget Responsibility (OBR), in Trade Union Congress (TUC) (2013) Four year real wage fall will cost average worker $£ 6,000$. Available online:

http://www.tuc.org.uk/economic-issues/economic-analysis/labour-market/four-yearreal-wage-fall-will-cost-average-worker-

Last accessed: 01/12/13).

OESC, 2008, OSCE human rights body concerned about anti-Roma violence in Italy. Available online: http://www.osce.org/odihr/49716

OSCE (2008) Roma in Europe miss out on security and prosperity, says OSCE High Commissioner on National Minorities. Available online:

http://www.osce.org/hcnm/49662 
Postone, M. (1980) Anti-Semitism and National Socialism. Notes on the German Reaction to "Holocaust", in: New German Critique 19, p. 97-115.

Revenga, A., D. Ringold, W. Tracy (2002) Poverty and Ethnicity: A Cross-Country Study of Roma Poverty in Central Europe. Washington, D. C.: The World Bank.

Scott,J.W. (2010) 'France's ban on the Islamic veil has little to do with female emancipation', The Guardian, 26/08/10. Available online:

http://www.theguardian.com/law/2010/aug/26/france-ban-islamic-veil

Sahlins, P. (2006) Civil Unrest in the French Suburbs, November 2005. Available online:

http://riotsfrance.ssrc.org/

Sargent, G. (2011) 'There's been class warfare going on for the last 20 years, and my class has won'. The Washington Post, 30/09/11. Available at:

http://www.washingtonpost.com/blogs/plum-line/post/theres-been-class-warfare-forthe-last-20-years-and-my-class-has-won/2011/03/03/glQApaFbAL_blog.html

Stockhammer, E. (2011) Peripheral Europe's Debt and German Wages. The Role of Wage Policy in the Euro Area, Research on Money and Finance Discussion Papers. Available online: http://researchonmoneyandfinance.org/media/papers/RMF-29-Stockhammer.pdf

Themelis, S. (2008) 'Labour Market Restructuring and Employment Pathways: the Case of a Mixed Community (Roma, non-Roma) in N.W. Greece' Romani Studies Journal, (18)2, pp. 123-154.

UNICEF (2010) Integration Subject to Conditions: A report on the situation of Kosovan Roma, Ashkali and Egyptian children in Germany and after their repatriation to Kosovo, UNICEF Kosovo, 2010 Williamson, J. (Ed.) (1994) The Political Economy of Policy Reform. Washington: Institute for International Economics.

Žižek, S. (2010) 'Barbarism With A Human Face', in These Times, Nov. 23. Available online:

http://www.inthesetimes.com/article/6641/barbarism_with_a_human_face/ 